\title{
Regulatory and Mechanistic Actions of Glucocorticoids on T and Inflammatory Cells
}

\author{
Ana C. Liberman ${ }^{1 \dagger}$, Maia L. Budziñski"t, Clara Sokn', Romina Paula Gobbini', \\ Anja Steininger ${ }^{1}$ and Eduardo Arzt ${ }^{1,2 *}$
}

${ }^{1}$ Instituto de Investigación en Biomedicina de Buenos Aires (IBioBA) - CONICET - Partner Institute of the Max Planck Society, Buenos Aires, Argentina, ${ }^{2}$ Departamento de Fisiología y Biología Molecular y Celular, Facultad de Ciencias Exactas y Naturales, Universidad de Buenos Aires, Buenos Aires, Argentina

OPEN ACCESS

Edited by:

Ana Rosa Pérez,

CONICET, Argentina

Reviewed by:

Tullio Florio,

Università di Genova, Italy

Luciano David D'Attilio,

CONICET Rosario, Argentina

${ }^{*}$ Correspondence:

Eduardo Arzt

earzt@iboba-mpsp-conicet.gov.ar

tThese authors have contributed equally to this work.

Specialty section: This article was submitted to Neuroendocrine Science, a section of the journal Frontiers in Endocrinology

Received: 12 January 2018 Accepted: 25 April 2018

Published: 16 May 2018

Citation:

Liberman AC, Budziñski ML, Sokn C, Gobbini RP, Steininger $A$ and Arzt $E$ (2018) Regulatory and Mechanistic Actions of Glucocorticoids on T and Inflammatory Cells.

Front. Endocrinol. 9:235. doi: 10.3389/fendo.2018.00235
Glucocorticoids (GCs) play an important role in regulating the inflammatory and immune response and have been used since decades to treat various inflammatory and autoimmune disorders. Fine-tuning the glucocorticoid receptor (GR) activity is instrumental in the search for novel therapeutic strategies aimed to reduce pathological signaling and restoring homeostasis. Despite the primary anti-inflammatory actions of GCs, there are studies suggesting that under certain conditions GCs may also exert pro-inflammatory responses. For these reasons the understanding of the GR basic mechanisms of action on different immune cells in the periphery (e.g., macrophages, dendritic cells, neutrophils, and T cells) and in the brain (microglia) contexts, that we review in this chapter, is a continuous matter of interest and may reveal novel therapeutic targets for the treatment of immune and inflammatory response.

Keywords: glucocorticoids, inflammation, FKBP51, transactivation, transrepression

\section{INTRODUCTION}

Living organisms must sustain a dynamic equilibrium in order to maintain homeostasis and survival which is constantly challenged by internal or external stressors. In order to appropriately cope with stressful stimuli, they have developed a highly conserved regulatory system. This neuroendocrine system consists mainly of the hypothalamic-pituitary-adrenal (HPA) axis and the autonomic nervous system. Glucocorticoids (GCs), are the end-product of the HPA axis, and play an important role in the maintenance of both resting and stress-related responses. If the stress response is dysregulated, homeostasis is altered and probably a wide range of adverse effects may appear on many vital physiological functions, such as growth, development, metabolism, reproduction, immune response, cognition, and behavior.

GCs act on almost all types of cells and in particular in the immune cells they have been shown to have powerful immunosuppressive and anti-inflammatory activities (1-5). As a result of their anti-inflammatory properties, GCs are widely used to help treat many different conditions, such as allergic, autoimmune, inflammatory, and hematological alterations. Interestingly, an accumulating body of evidence now strongly suggests that GCs can have both pro- and anti-inflammatory roles under specific conditions. The pro-inflammatory activity of GCs is most apparent in the central nervous system (CNS). These opposite effects work together in order to resolve cellular responses to inflammatory stimuli and also as a protective mechanism "priming" the immune cells to efficiently respond to the noxa or stressor and then restore homeostasis (6). 
Upon peripheral or cerebral immune stimulation, the HPA axis is activated. When the immunogenic stress occurs in the brain, local inflammatory components activate the HPA axis. However, if the challenge takes place outside the brain, multiple pathways bring together stimulatory signals from the periphery to the HPA axis. Mounting evidence suggests that cytokine signals access to the brain through different pathways. These pathways mainly include: cytokines passing across the blood-brain barrier; by specific saturable transport molecules on the brain endothelium; activation of endothelial cells of brain capillaries that release second messengers within the brain parenchyma; transmission of cytokine signals via afferent nerve fibers and finally by peripherally activated monocytes that can enter into the brain (7-11). The induction of these different mechanisms modulates cytokine activity in the brain (12-14).

The accurate regulation of the HPA axis activity is critical, since GC imbalances can result in many different pathological conditions $(13,15)$. Long-term treatment with GCs may result in a plethora of harmful undesired side effects, such as diabetes, hypertension, growth retardation, dyslipidemia, osteoporosis, glaucoma, muscle atrophy, and is also related to many important behavioral alterations, among others $(16,17)$. Chronic exposure to GCs can also be associated with GC insensitivity, reducing the efficacy of the therapy (18). Also, alterations or deficits in the HPA axis response are tightly associated with a wide range of autoimmune and inflammatory diseases (19-24).

In this review, we will discuss the role of GCs on the immune and inflammatory cells in the periphery and also the physiological importance and mechanisms implicated in the apparent paradoxical functions of GCs in the brain in order to appropriately maintain a coordinated homeostatic response.

\section{THE GLUCOCORTICOID RECEPTOR (GR)}

As a small lipophilic hormone, GCs can rapidly diffuse into cells and exert their main actions. These actions are elicited by the binding of GCs to their intracellular receptor, the GR. The GR is a hormone-activated transcription factor (TF) that belongs to the superfamily of nuclear hormone receptors (25). GR is a modular protein composed of three distinct regions with different functions (Figure 1A). The N-terminal domain (NTD) contains a transactivation domain called activation function 1 (AF1) that is responsible for the transcriptional activation and is implicated in the association with coregulators and the basal transcription machinery. The DNA-binding domain (DBD) is composed of two zinc fingers that have been shown to be important for GR homodimerization and DNA-binding specificity. The hinge region, which separates the DBD from the ligand binding domain (LBD), is a flexible linker structure which is implicated in allowing proper DNA binding, dimerization, and nuclear translocation of the receptor (26). The C-terminal LBD, contains the ligand binding site and a second transactivation domain (AF2) regulated by hormone binding (27). The AF2 transactivation domain is important for the interaction with co-chaperones, coregulators, and other TFs (28). The LBD also encompasses a dimer interface which is critical for GR function and the binding of the heat shock protein (Hsp) 90 (29). The DBD and LBD both contain nuclear localization signals, which are important for GR nuclear translocation. The DBD also contains the nuclear export signal sequence (NES) which targets it for export from the cell nucleus to the cytoplasm through the nuclear pore complex.

Some degree in the heterogeneity in GR proteins may result from alternative splicing (30) (Figure 1B). The specificity and sensitivity of different target tissues to GCs has been reported to be related to GR isoforms (30). The GR $\alpha$ is the predominant isoform, and it is the one that transduces GCs signaling in the cell (31). There are other four additional splice variants identified: GR $\beta$, GR $\gamma$, GR-A, and GR-P. GR $\beta$ differs from GR $\alpha$ in the carboxy terminal sequence, rendering GR $\beta$ non-responsive to GCs (32, 33), with no transcription of target genes. Therefore, GR $\beta$ can be described as a dominant negative inhibitor of GR $\alpha$ activity. GR $\beta$ does not bind GC agonists, however, it does bind to the GR antagonist RU-486 (34). GR $\beta$ can inhibit GR $\alpha$ transcriptional activity by different molecular mechanisms including competition for glucocorticoid response elements (GRE), interference with the activity of coregulators, and formation of inactive dimers $(35,36)$. In most tissues, GR $\beta$ is expressed at very low levels. However, abundant GR $\beta$ expression has been described especially in some inflammatory cells, such as lymphocytes and macrophages, and have been related to GCs resistance in diseases such as asthma (37), rheumatoid arthritis (38), ulcerative colitis (39), systemic lupus erythematosus (40), and acute lymphoblastic leukemia and chronic lymphocytic leukemia $(41,42)$. Considering that GR $\beta$ can inhibit GR $\alpha$ activity, the modulation of GR $\alpha / G R \beta$ expression ratios may be an interesting approach to regulate GC sensitivity $(42,43)$. In addition, eight alternative translation initiation sites increase the repertory of GR proteins to almost 40 distinct isoforms of GR protein (44) (Figure 1B).

At the cellular level, GC availability is also modulated by

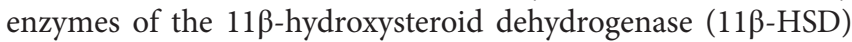
family, mainly $11 \beta$-HSD1 and $11 \beta-H S D 2$ which regulate the conversion of active cortisol into inactive cortisone. 11 $\beta$-HSD1 favors the conversion of cortisol from cortisone, increasing local GC activity (45). In contrast, $11 \beta$-HSD2 catalyzes cortisol to cortisone, thereby reducing GC availability. Thus, the balance in the expression of these two enzymes in a given tissue or cell, regulates GC-mediated responses. In addition, some studies show that inflammatory cytokine signaling modulates the relative expression of $11 \beta$-HSD genes, favoring $11 \beta$-HSD 1 and inhibiting $11 \beta$-HSD2 $(46,47)$, adding another level of regulation of GC activity.

Another important level for fine-tuning the cellular response to GCs in different environmental situations is the modulation of GR activity by posttranslational modifications (PTMs). These PTMs include phosphorylation, acetylation, ubiquitination, and sumoylation, which may accurately regulate GR activity in response to diverse external stimuli (48) (Figure 1A). In particular, SUMO conjugation has been extensively described to modulate GR transcriptional activity (49-52). GR contains three consensus sumoylation sites. Two sumoylation sites located at the NTD have been demonstrated to be part of the synergy control (SC) motif sequence (50). The SC motifs consist of short regulatory sequences which are important for inhibiting the synergistic transactivation. SUMO conjugation to the two 
A

\section{GR domains}

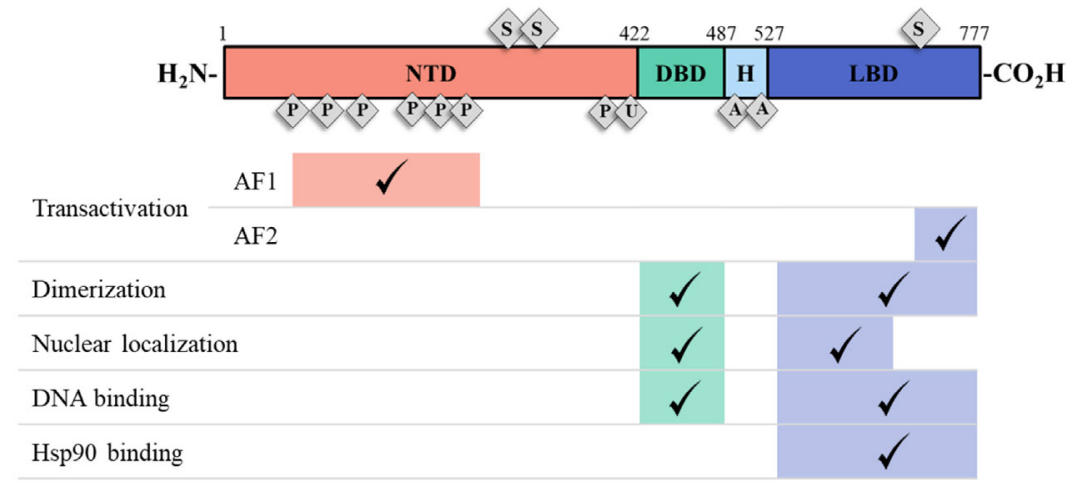

B

GR gene, splice variants and translational isoforms
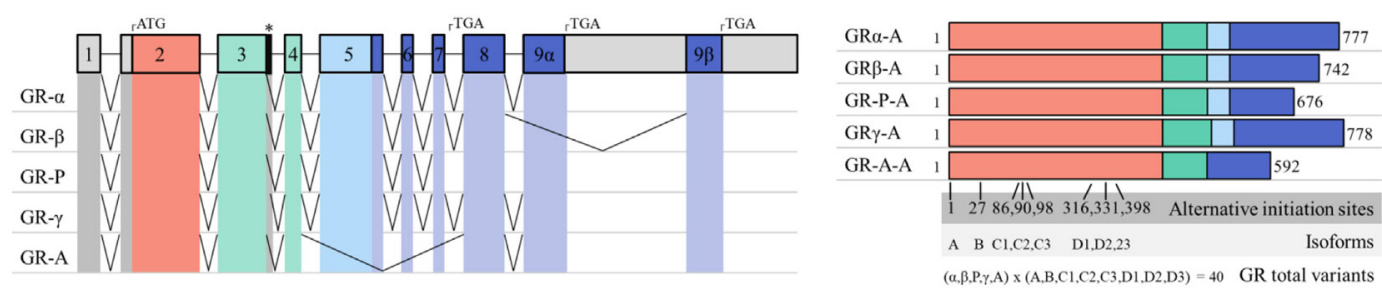

C

GR regulation of gene expression

Direct DNA binding

(Transactivation)

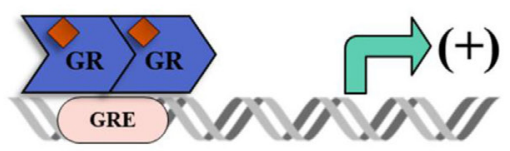

Direct DNA binding on nGREs

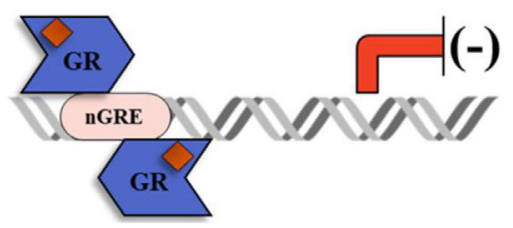

Composite

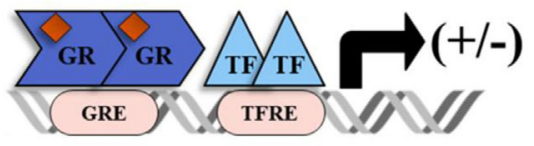

Tethering

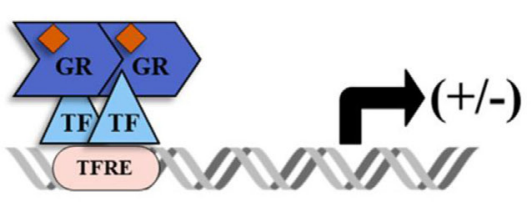

FIGURE 1 | The glucocorticoid receptor (GR) structure, isoforms, and mechanisms of transcriptional regulation. (A) Full human GR $\alpha$ protein has an N-terminal domain (NTD), a DNA-binding domain (DBD), a ligand binding domain (LBD) and a hinge region (H) between DBD and LBD. They have different associated functions, e.g., transactivation, dimerization, nuclear localization, DNA binding, and heat-shock protein 90 binding. The receptor can be post-translationally modified by phosphorylation (P), ubiquitination (U), acetylation (A) and sumoylation (S). Regions associated with transactivation (activation function 1 and 2: AF1 and AF2) are shown. (B) The GR has various isoforms which result from alternative splicing and multiple transcriptional start sites at exon 2. The colors indicate NTD (red, exon 2), DBD (green, exons 3-4), H (light blue, exon 5) and LBD (dark blue, exon 5-9). The 5' and 3'-untranslated regions are colored in gray. There are five patterns of alternative splicing that result in GR isoforms $\alpha, \beta, P, \gamma, A$. Each of them has eight translational variants (A, B, C1, C2, C3, D1, D2, D3) depending on the transcriptional start site ("*” denotes an alternative splice donor site in the intron between exons 3 and 4). (C) The GR, carrying GC ligand, translocates to the nucleus and regulates gene expression. GR can directly activate/inactivate gene expression by interacting with GREs/nGREs, it can bind to GREs and modulate gene transcription by interacting with neighboring DNA-bound transcription factors (TFs) (composite mechanism) and it can act by attaching itself to DNA-bound TFs (tethering mechanism). Abbreviations: TF, transcription factor; GRE, glucocorticoid response element; nGRE, negative glucocorticoid response element; TFRE, transcription factor response element. 
NTD sumoylation sites is responsible for the functional effect of the SC motifs and thereby they inhibit GR activity $(50,53)$ (Figure 1A). It has also been demonstrated that in the presence of the sumoylation enhancer, RSUME (54), a SUMO peptide is conjugated to the third sumoylation site located in the LBD of the GR. Sumoylation in the LBD may be important for inducing GR-mediated transcriptional regulation during stress adaptation (55) (Figure 1A). A genome-wide analysis of GR sumoylation impact on gene expression, showed that genes differentially regulated by this PTM are mostly related to proliferation and apoptosis pathways and also strongly suggests that sumoylation can regulate genome-wide chromatin occupancy of the GR (56). Also, GR SUMO conjugation is influenced by other PTMs such as phosphorylation in order to fine-tune GR transcriptional activity in a target gene-specific manner (57). Important coregulators of the GR are also modified by SUMO conjugation, such as Hsp90, GRIP1, and also FKBP51, further regulating GR activity (58-62). Therefore, PTMs that impact on the GR but also on key molecules that fine-tune its activity, helps to understand the complexity of GR-mediated regulation of its target gene expression $(2,48)$.

\section{GCs ANTI-INFLAMMATORY ACTIONS}

The GR forms complex with chaperone molecules, such as Hsp90 and 70, and immunophilins, such as FKBP51, FKBP52, Cyp44, and PP5 (63). FKBP51 binds to the unbound GR and reduces GR activity mainly by reducing GR hormone binding and its nuclear translocation. Therefore, FKBP51 is considered as an inhibitor of GR transcriptional activity. Upon ligand binding, the GR exchanges FKBP51 for FKBP52, which is able to interact with the dynein motor protein, facilitating GR translocation to the nucleus (64). Interestingly, FKBP51 overexpression has been associated with GC resistance in autoimmune diseases. FKBP51 expression was found to be enhanced in sputum samples from patients with chronic obstructive pulmonary disease (65). Moreover, in a genome-wide profiling focused on the identification of epithelial gene markers of asthmatic patients and response to corticosteroids, GC treatment was found to induce FKBP51 expression, which in turn was associated with a poor response to corticosteroids, suggesting a role of FKBP51 in GC resistance $(66,67)$. Also, enhanced expression of FKBP51 has been found in bone marrow cells in patients with rheumatoid arthritis (68). Evidence also suggests that FKBP51 modulates NFkB-dependent gene expression, with possible implications for various inflammatory and immune pathways (69-73). Considering that GR is a key modulator of immune and inflammatory responses, FKBP51 dysregulation may provide the basis for a role of FKBP51 in these processes (66). Moreover, FKBP51 has recently been shown to be a target of SUMO conjugation and that sumoylation of FKBP51 is necessary for its association to Hsp90 and modulates FKBP51-mediated inhibition of GR activity in neuronal cells (58). In the brain, FKBP51 has been shown to be important for the development of psychiatric diseases and the response to antidepressant treatment, suggesting that regulation of FKBP51 activity might be an interesting approach for modulating GR outcome in the stress response and also in the inflammatory context (74-76).
Once in the nucleus, the activated GR can regulate gene expression by different mechanisms known as genomic effects (Figure 1C) (27). The genomic mechanism involves changes in the levels of specific genes: binding of GR to GREs in the promoters of its target genes and activation of transcription (transactivation); DNA binding of the GR with other TFs to "composite" elements which contain a GRE and an overlapping response element of another TF (binding can lead to gene activation or repression); or binding of the GR to a TF (e.g., NFkB; or AP1) by means of a "tethering" mechanism without contacting DNA, to influence the activity of the TF (this mechanism is considered to be the prevailing mechanism for transrepression) $(2,77,78)$. Furthermore, GR-mediated transcriptional repression can be exerted via GR binding to a negative GRE (nGRE) (79). Binding to these nGRE prevent receptor dimerization through a strong negative cooperativity and alters the conformation of GR residues that are critical for transcriptional activation so that negative regulation is accomplished (80). A growing body of evidence shows that GC can also mediate non-genomic actions that do not require protein synthesis and are implicated in rapid cellular responses. For example, in the cytoplasm the activated GR can acutely interact with signaling pathways, such as PI3K, JNK, 14-3-3 proteins, and components of the $\mathrm{T}$ cell receptor signaling complex (81), modulating pro-inflammatory gene expression. In thymocytes, the activated GR can translocate to mitochondria and induce a rapid apoptotic response (82). In addition, membrane-bound GR on monocytes was reported to mediate non-genomic effects (82). On the other hand, binding of GCs to GR can modify the recruitment of different factors such as the multiprotein chaperone complex that participate in many signaling pathways, modifying secondary signaling cascades and, therefore, may further regulate the immune response $(78,83)$. GCs may also exert anti-inflammatory responses by direct negative interaction with components of the MAPK pathway, such as ERK, c-Jun NH2-terminal kinases (JNK), and p38 isoforms (p38) regulating their activity (84). Further studies are required to clarify the implications of non-genomic GC-mediated activity in the immune and inflammatory context.

It has been shown that several of the undesirable metabolic side effects associated with chronic GC treatment are mediated via transactivation. However the anti-inflammatory effects of GCs are mainly mediated via the transrepression elicited by a monomeric GR with the activity of TFs, such as NFkB and AP1 (1-3, $85)$. These TFs are involved in the activation of pro-inflammatory and immunoregulatory genes, such as inflammatory cytokines, cytokine receptors, adhesion molecules, and chemotactic proteins that play a key role for the coordination of the inflammatory response $(1,86-88)$. The first example of the transrepressive mechanism was the inhibitory interaction described between GR and AP1 (89), which results in the inhibition of IL2 expression (90). NFkB is present in almost all immune cells and regulates the expression of inflammatory cytokines. Thus, inhibition of $\mathrm{NFkB}$ activity is an important feature for GR-mediated antiinflammatory activity $(85,91)$. It also inhibits NFAT-dependent IL2 transcription (92). The main mechanism of the GR action over these TFs is via transrepression: the activated GR acts by binding proximal to the NFkB or AP1-binding site and interacts 
with these TFs inhibiting gene expression (93). The transrepression mechanism is not restricted to these TFs, but has expanded including among others, CREB, STAT, and T-bet $(1-3,94)$.

Alterations in chromatin structure have been reported to be important for regulating GC actions. The GR can differentially interact with proteins that have histone acetyltransferase (HAT) activity, but also with histone deacetylases and kinases that can influence the chromatin environment modifying chromatin accessibility and further regulating immune and inflammatory gene expression (3). In addition, chromatin accessibility has been reported to pre-determine GR binding patterns and, therefore, is critical for cell-specific outcome, providing new molecular basis for the tissue selectivity $(95,96)$. By all these different mechanisms, GCs regulate important functions, not only in the periphery but also in the brain.

Synthetic analogs of GC are often employed in the clinic in the therapy of allergic, inflammatory, and autoimmune disorders (97-99). It is generally accepted that GR-mediated transrepression holds the beneficial anti-inflammatory action, whereas their side effects are due mainly to the direct binding of GR to GREs as depicted before (98-100). However, transactivation is also necessary for the induction of several anti-inflammatory genes, such as MAP kinase phosphatase 1 (101), glucocorticoid-induced leucine zipper (102), and inhibitor kappa B-alpha $(\mathrm{IkB} \alpha)(85)$. Therefore, the ideal GC analogs should be those that have high repressive activity against inflammatory mediators, but low transactivation activity, causing minimal side effects. Several steroidal and nonsteroidal ligands have been reported to have this dissociated function between transactivation and transrepressive mechanisms $(97-99,103)$. These compounds were shown to repress the activity of key inflammatory and immune TFs in vivo (104-107). However, GCs can induce gene expression not only by binding to GRE, but also in combination with other TFs and also by binding to promoter regions in a mechanism that does not involve GR dimerization or DNA interaction; therefore, unexpected secondary side effects might appear (78).

GCs may exert acute anti-inflammatory effects through the release of annexin-A1 (ANXA1) (108). Originally, this protein was suggested to have anti-inflammatory actions because it was described to inhibit phospholipase A2 (109). However, ANXA1 has been reported to regulate different cellular processes, such as migration, growth, differentiation, apoptosis, membrane fusion during exocytosis, lipid metabolism, and cytokine expression. Importantly, in the HPA axis, ANXA1 has been reported to play a critical role in the negative feedback exerted by GCs, therefore, affecting hypothalamic-releasing hormones secretion possibly via non-genomic mechanisms (110).

\section{GCs ACTIVITY ON PERIPHERAL IMMUNE CELLS}

GCs mediate immunosuppressive functions by acting on almost all types of immune cells (Figure 2). GCs can regulate the phenotype, survival, and functions of monocytes and macrophages which have crucial roles in tissue homeostasis and innate immunity. GCs exhibit anti-apoptotic effects promoting the survival of anti-inflammatory macrophages (111). The intrinsic molecular mechanism involves a prolonged induction of the extracellular signal-regulated kinase/MAPK (ERK/MAPK) pathway resulting in inhibition of caspase activities and expression of anti-apoptotic genes (111). GCs can also improve the phagocytic activity of these cells and stimulate the clearance of harmful elements, such as neutrophil clearance (112-114). GCs also suppress immunostimulatory functions of these cells and inhibit the release of various pro-inflammatory mediators, such as cytokines, chemokines, and reactive oxygen through different mechanisms $(115,116)$. Functional clustering of GC-regulated genes by human antiinflammatory macrophages by microarray technology indicated induction of phagocytosis and motility as well as repression of adhesion, apoptosis, and oxidative burst $(117,118)$.

GCs can regulate the maturation, survival, and migration toward the lymph nodes and motility of dendritic cells (DCs), and also inhibit their immunogenic functions (Figure 2). GCs were shown to reduce the ability of DCs to stimulate T cells by inhibiting the upregulation of co-stimulatory molecules and cytokines, such as IL6, IL12, and TNF $\alpha$ and by inducing the tolerance-inducing transcription factor GILZ (119-125). The distinct actions exerted by GCs in immature and mature DCs are due to differential expression of GR translational isoforms (126).

GCs are important modulators of neutrophilia (Figure 2). Leukocyte extravasation is the movement of leukocytes out of the circulation and toward the site of tissue damage or infection. Rolling, adhesion, activation, and transmigration are necessary to arrive to the damaged tissue. GCs can modulate each of these steps. Rolling and adhesion is mediated by the interaction of the leukocyte integrins with the endothelial counterparts, which are inhibited by GCs (127-129). Also, GCs increase the number of circulating neutrophils in the blood stream by favoring their egress from the bone marrow and also inhibiting their migration to inflammatory sites by hindering the expression of adhesion molecules $(32,129,130)$.

GCs exert distinct immunomodulatory actions on $\mathrm{T}$ cells (Figure 2). GCs decrease the number of circulating $\mathrm{T}$ cells by favoring their migration back to the bone marrow and secondary lymphoid tissues or through the induction of chemokine receptors, adhesion molecules, and matrix metalloproteinases $(131,132)$. The steroid hormone also favors $\mathrm{T}$ cells apoptosis. GC-induced apoptosis of $\mathrm{T}$ cells requires the dimerization of the GR (133) and is mediated via the induction of Puma and Bim expression (134-137). The relative expression of distinct GR isoforms increases the susceptibility of T cells to GC-induced cell death (138). Helper T (Th) cells are important players of the adaptive immunity (1). Upon antigen stimulation, naive Th cells can differentiate into different subsets: Th1, Th2, Th17, or regulatory $\mathrm{T}$ (Tregs) cells among others, each with specific effector functions. Th1 cells express the lineage-specific TF T-bet and STAT4 and release pro-inflammatory cytokines, such as IFN $\gamma$ and IL2 (139). Th1 cells help in the activation of effector $\mathrm{T}$ cells, natural killer (NK) cells, and macrophages at the site of infection, promote effective immune responses against intracellular pathogens and are also implicated in autoimmune pathologies. Th2 lymphocytes selectively express the TF GATA3 and are characterized by the expression of IL5, IL4, IL10, and IL13 and are important for the 


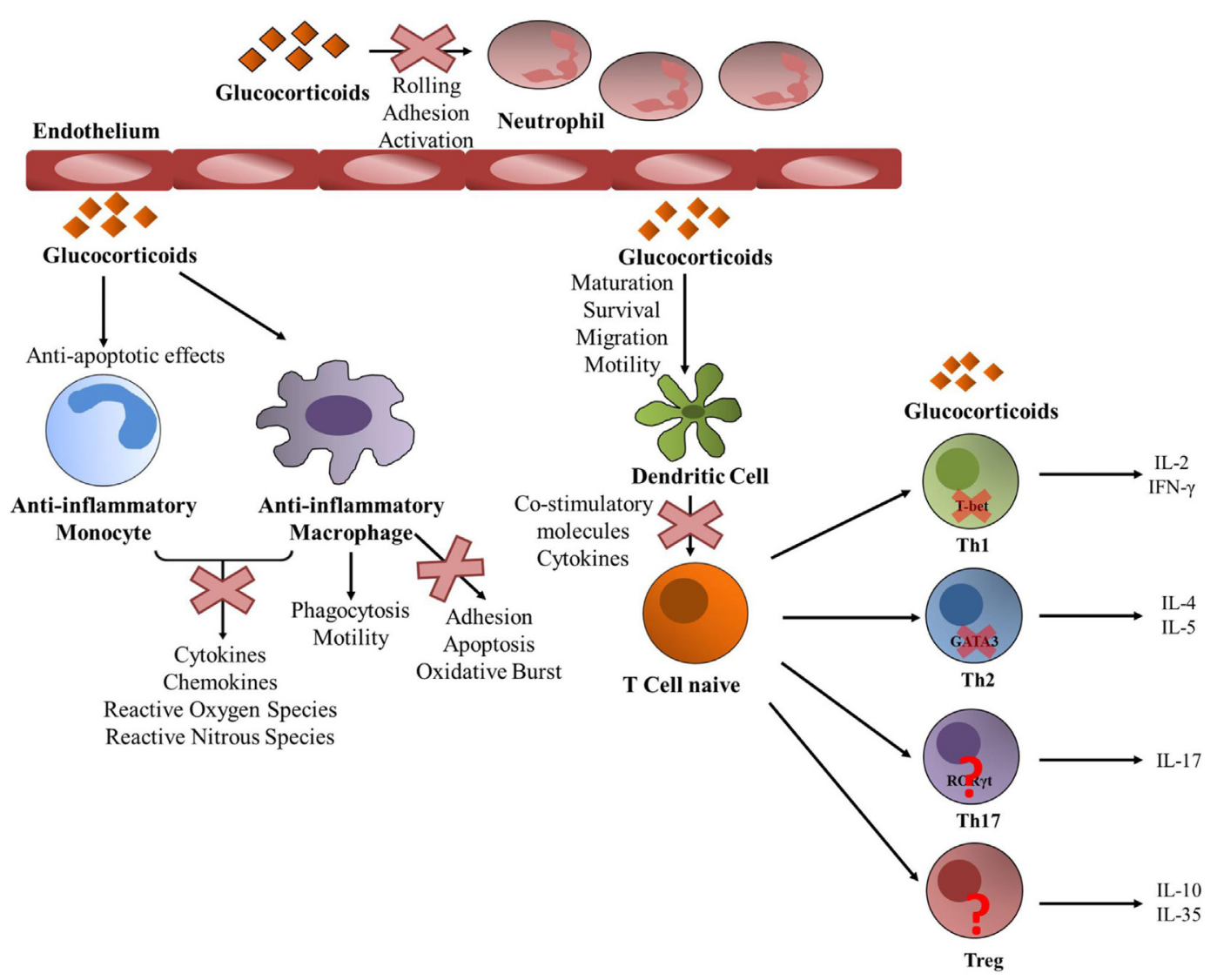

FIGURE 2 | Glucocorticoid (GC) activity on periphery immune cells. GCs act upon almost every immune cell type. GCs promote an anti-inflammatory state on both monocytes and macrophages. GCs prevent monocytes into entering apoptosis and inhibit the liberation of pro-inflammatory mediators by both types of cells. Particularly in macrophages, GCs promote phagocytosis and motility, while they inhibit adhesion, apoptosis and oxidative burst. They also act upon neutrophils function by inhibiting rolling, adhesion and activation. GCs act toward dendritic cells by promoting their maturation, survival, migration and motility, and at the same time GCs inhibit their ability to activate T cells by suppressing the production of pro-inflammatory molecules. A naïve helper $T$ (Th) cell can differentiate into different Th lineages and GCs exert different actions. They act upon Th1 by decreasing T-bet transcriptional activity and suppressing the production of pro-inflammatory molecules such as IL-2 and IFN $\gamma$. They also suppress GATA3 activity in Th2 cells inhibiting the expression of IL-4 and IL-5. The action of GCs toward Th17 and regulatory $\mathrm{T}$ cells is not yet well understood.

proper eradication of extracellular pathogens (140). Also, Th2 cells activate $\mathrm{B}$ cells to produce antibodies and play a triggering role in the activation/recruitment of eosinophils and mast cells in allergic responses. IL17-producing Th17 cells selectively express ROR $\gamma t$ and also $\operatorname{ROR} \alpha(141,142)$. Th17 cells play an important role in autoimmune diseases and in host defense against infection. Treg cells mainly express the TF Foxp3 and inhibit effector T-cell differentiation and proliferation and suppress autoimmune and allergic responses (143). GCs inhibit the expression of many $\mathrm{T}$ cell cytokines (1) and can produce a shift from Th1-mediated cellular immunity to mediating humoral Th2 responses at physiological doses or chronic treatment (144). Upon acute treatment with GCs, they inhibit the synthesis of Th1 cytokines like IL2 and IFN $\gamma$ and reduce STAT4 activity (145) and also reduce Th2 cytokines expression (146). The molecular mechanism by which GCs inhibit Th1 responses involves the reduction of T-bet transcriptional activity by the inhibitory interaction between GR and T-bet that results in diminished binding of T-bet to DNA
(94) (Figure 2). Also GCs where shown to reduce mRNA and protein levels of T-bet (94). The activity of the Th2-specific TF GATA3 is also suppressed by GCs via two main mechanisms: first by GR-mediated inhibition of GATA3 translocation into the nucleus and second by the inhibition of GATA3 phosphorylation by GC-induced MKP1 expression $(147,148)$ (Figure 2). Furthermore, STAT6 activity also involved in Th2 differentiation is inhibited by GCs (149). How GCs modulate Th17-mediated responses has not been extensively studied, and the importance of Th17 modulation by GCs for the suppression of allergic or autoimmune diseases remains unclear (150). In rheumatoid arthritis, GC treatment diminished IL17 levels (151). In addition, in rat lymphocytes methylprednisolone inhibited IL17 expression due to the inhibition of ROR $\gamma$ t expression (152) (Figure 2). However, several studies strongly suggest that GC resistance is associated with a pathogenic inflammatory Th17 phenotype that is refractory to GCs $(150,153,154)$. Recently, a gene-expression profiling to characterize the steroid-resistant phenotype showed 
that Th17 cells have restricted genome-wide responses to GCs and that they are refractory to GC inhibition at this level. In addition, Th17 cells were sensitive to suppression with the calcineurin inhibitor, cyclosporine A, suggesting that the clinical efficacy of cyclosporine $\mathrm{A}$ in the treatment of steroid resistance may be due to its selective inhibition of Th17 cells (155). Another interesting study has shown that Th17 cells are insensitive to GC-induced apoptosis and had high levels of BCL-2, knockdown of which sensitized Th17 cells to GC-induced cell death (156). Also, lung Th17 development in the murine severe asthma model was enhanced by GCs, supporting a role of Th17 cells in GC-refractory inflammatory conditions such as asthma (157).

In contrast to the inhibitory effect of GCs on pro-inflammatory effector $\mathrm{T}$ cells, it has been shown that Treg cells, which are key suppressors of $\mathrm{T}$ cell-dependent immune responses, are enhanced upon dexamethasone treatment by being more resistant to GC-induced cell death (158) (Figure 2). Also, GCs where shown to amplify IL2-dependent expansion of Treg cells and to enhance their capacity to reduce experimental autoimmune encephalomyelitis (EAE) in mice (159). In addition, GCs increase the percentage of Treg cells that express Foxp3 in patients with multiple sclerosis (160). In vivo, T cell-specific targeted GR deletion in pregnant animals undergoing EAE, resulted in a reduction of Treg population and a loss of pregnancy-induced protection, suggesting that steroid hormones can shift the immunological balance in favor of Tregs via differential engagement of the GR in T cells (161). However, others have found that GC treatment suppresses the expression of Foxp3 Tregs in an EAE model (162) and also in lungs of allergic mice (163).

In addition to their well-studied anti-inflammatory and immunosuppressive activity, an increasing body of evidence has revealed situations in which GCs have the opposite effect. This has been shown to depend on the dose, timing, duration of exposure, and cell population or tissue analyzed (164). The paradoxical proinflammatory role of GCs is mostly evident in the brain, where accumulating evidence show that GCs elicit different immune responses depending on the affected brain regions.

\section{GCs ACTIONS IN THE BRAIN}

There is a significant body of evidence indicating that GCs can suppress the innate immunity in the brain after a peripheral or cerebral challenge (23). In this way, in adrenalectomized mice, there is an induction in the levels of pro-inflammatory cytokines in the brain following LPS injection (165-168). Studies also demonstrated that GCs inhibit the release of pro-inflammatory mediators in microglial cells treated with LPS $(169,170)$. Experiments performed in vivo support these findings by revealing that dexamethasone causes a strong reduction in LPS induction of NFKB expression in the brain (171). In addition, COX inhibitors were demonstrated to increase the expression of pro-inflammatory genes in the brain during systemic inflammation by reducing the activation of the HPA axis and the release of GCs $(172,173)$. This same effect took place when the GR antagonist RU486 was administrated $(172,173)$. Also, systemic inflammation, through the increase in circulating GCs, has been reported to have the ability to prevent the cerebral innate immune response induced by intraparenchymal endotoxin injection (174). Mice treated with the GR antagonist RU486 before intracerebral LPS administration showed an increase in the pro-inflammatory response, which in turn induced neuronal death. These findings suggest that GCs are important for protecting the brain during innate immunity (175, 176). Interestingly, when mice lacking GR in microglia were challenged with an intracerebral administration of LPS, the activation of the toll-like receptor 4 signaling pathway induced cellular lesion, and also neuronal and axonal damage (177). In addition, microglial cell cultures have reduced motility and increased amoeboid morphology in the absence of GR expression. This study strongly suggests that microglial GR is the principal mediator preventing neuronal degeneration triggered by LPS and that it also contributes to the protection of other cell types (177), having an important role in promoting neuronal survival.

The majority of GC pro-inflammatory activity has been described in animal models of acute or chronic stress which occurred previous to peripheral or cerebral immune challenges. For instance, acute stressors were reported to induce the expression of pro-inflammatory cytokines in specific brain regions, such as the hippocampus, following LPS peripheral challenge (178-180). GCs were also found to upregulate microglial activation markers including the toll-like receptor 2 pro-inflammatory pathway $(178,181)$ (Figure 3A). It was also shown that chronic unpredictable stress was able to potentiate LPS-mediated activation of NFkB activity in the frontal cortex and hippocampus via GC production (182). Also, chronically stressed animals that were

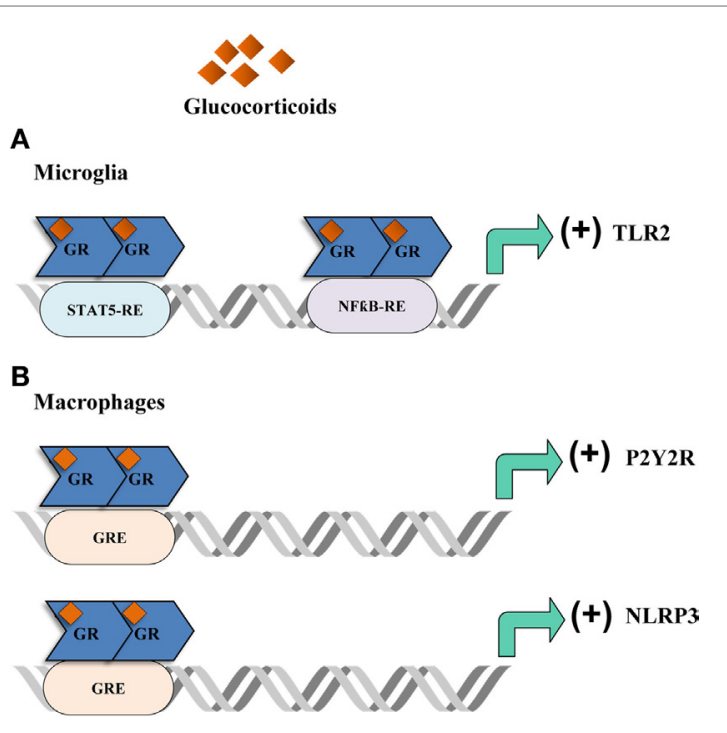

FIGURE 3 | Glucocorticoids (GCs) actions in the brain. Acute stressors promote an inflammatory phenotype in the brain. (A) In the microglia, GCs bind to the glucocorticoid receptor (GR) which then promotes the translation of the toll-like receptor 2 (TLR2) by interacting with STAT5 and NFkB response elements. TLR2 then exerts a pro-inflammatory response by promoting the production of inflammatory cytokines. (B) In macrophages, GCs promote the expression of the purinergic receptor P2Y2R which then produces IL-6 in response to ATP. Moreover, GCs enhance the expression of NLRP3 which in turn promotes the production of pro-inflammatory cytokines. 
injected with LPS in the prefrontal cortex or the hippocampus, exhibited microglia activation, an increase in pro-inflammatory mediators and loss of astroglia and neurons. These effects were reduced with RU486 administration $(183,184)$. The prefrontal cortex is important in many brain functions and is a target for neurodegenerative diseases. It has been reported that in this brain region, TNF $\alpha$ expression and activation of MAPK signaling pathway is upregulated by chronic stress after intracortical LPS injection in a GR-dependent manner suggesting a synergistic effect between inflammation and stress. This fact could ultimately explain the relationship described between stress and some neurodegenerative pathologies $(183,184)$. In order to investigate if stress-induced GCs is responsible for the response of brain immune cells to pro-inflammatory stimuli, animals were acutely stressed and $24 \mathrm{~h}$ later hippocampal microglia were challenged with LPS ex vivo. Treatment in vivo with RU486 and adrenalectomized inhibited the microglial pro-inflammatory response, indicating that stress-induced GCs are able to sensitize the microglial pro-inflammatory function $(185,186)$. Therefore, stress may act "priming" central innate immunity to a subsequent immune challenge by making the neuroimmune context more responsive to inflammation, also favoring GC insensitivity or reducing the HPA response (187). In addition, acute restraint stress, inescapable tail shock and other stressors induce many inflammatory mediators, reduce immunoregulatory proteins and trigger microglia activation and proliferation (188-193). In addition, GCs have been reported to increase the expression of the purinergic receptor P2Y2R (Figure 3B) which promotes the secretion of inflammatory mediators in response to ATP (194). Recent data also indicate that GCs induce the expression of NLRP3 (NLRP3: nucleotide-binding domain, leucine-richcontaining family, pyrin domain-containing 3 ) in macrophages, which is a critical component of the inflammasome (Figure 3B). The GC-dependent induction of NLRP3 sensitizes the cells to extracellular ATP and significantly enhances the ATP-mediated release of pro-inflammatory molecules. This effect was specific for GCs and dependent on the GR and suggests that GCs sensitize the initial inflammatory response in the context of acute cellular damage or death (32). In addition, GCs and TNF $\alpha$ were shown to coregulate immune gene expression when combined (195). These results suggest that the final outcome of GCs pro- or anti-inflammatory activity depends on the activation state and signaling context. GCs are also able to modulate the inflammatory response to LPS in different ways according to the brain region (180, 182). For example, GR activation during chronic stress increases LPS-induced NFKB activation and TNF $\alpha$, IL1 $\beta$, and iNOS expression in the hippocampus and frontal cortex,

\section{REFERENCES}

1. Liberman AC, Druker J, Perone MJ, Arzt E. Glucocorticoids in the regulation of transcription factors that control cytokine synthesis. Cytokine Growth Factor Rev (2007) 18:45-56. doi:10.1016/j.cytogfr.2007.01.005

2. Petta I, Dejager L, Ballegeer M, Lievens S, Tavernier J, De Bosscher K, et al. The interactome of the glucocorticoid receptor and its influence on the actions of glucocorticoids in combatting inflammatory and infectious but exhibits contrary effects in the hypothalamus (182). It is important to keep in mind that a pro-inflammatory context does not necessarily mean that damage will take place. Timing is a key parameter that will determine the final outcome of the inflammatory response. While exaggerated inflammation can favor neuronal dysfunction and cell death, pro-inflammatory mediators may at first induce the removal of the pathogen, the recruitment of immune cells and initiate tissue remodeling in order to appropriately cope with the pathogen and therefore, restoring homeostasis.

\section{CONCLUSION}

GCs are widely used in the clinic to control not only peripheral, but also CNS inflammatory response. However, the prolonged administration of this steroid hormone is often ineffective and can even worsen the outcome of the disease. Considering the known undesirable metabolic side effect, the induction of proinflammatory responses and the existence of GC resistance, GCs should be used carefully. Future research should be focused not only in understanding the molecular basis of GCs side effects and resistance, but also in dissecting how GCs induce proinflammatory responses in order to avoid serious detrimental consequences, particularly in the brain. In the future, a combination of different therapeutic approaches may lead to a more effective treatment and may help to lower the doses or duration of GC treatment thus minimizing the risk of toxicity and drug resistance (196). Finally, taking into account inter-individual differences in patient responsiveness to GC treatment, where different molecular mechanisms might be implicated, future directions should be in support of a customized and personalized treatment to meet individual patient needs.

\section{AUTHOR CONTRIBUTIONS}

AL: wrote, discussed, and corrected the manuscript. MB: discussed and corrected the manuscript. CS: discussed and corrected the manuscript, performed the figures. RG: discussed and corrected the manuscript, performed the figures. AS: corrected the manuscript. EA: discussed and corrected the manuscript.

\section{FUNDING}

This work was supported by grants from the Max Planck Society, Germany; the University of Buenos Aires; CONICET; the Agencia Nacional de Promoción Científica y Tecnológica, Argentina; and FOCEM-Mercosur (COF 03/11). 
cytokines and glucocorticoids. Immunol Cell Biol (2001) 79:385-94. doi:10.1046/j.1440-1711.2001.01023.x

5. Stahn C, Buttgereit F. Genomic and nongenomic effects of glucocorticoids. Nat Clin Pract Rheumatol (2008) 4:525-33. doi:10.1038/ncprheum0898

6. Busillo JM, Cidlowski JA. The five Rs of glucocorticoid action during inflammation: ready, reinforce, repress, resolve, and restore. Trends Endocrinol Metab (2013) 24:109-19. doi:10.1016/j.tem.2012.11.005

7. D’Mello C, Le T, Swain MG. Cerebral microglia recruit monocytes into the brain in response to tumor necrosis factoralpha signaling during peripheral organ inflammation. J Neurosci (2009) 29:2089-102. doi:10.1523/ JNEUROSCI.3567-08.2009

8. Konsman JP, Parnet P, Dantzer R. Cytokine-induced sickness behaviour: mechanisms and implications. Trends Neurosci (2002) 25:154-9. doi:10.1016/ S0166-2236(00)02088-9

9. Plotkin SR, Banks WA, Kastin AJ. Comparison of saturable transport and extracellular pathways in the passage of interleukin-1 alpha across the blood-brain barrier. JNeuroimmunol (1996) 67:41-7. doi:10.1016/ S0165-5728(96)00036-7

10. Rivest S, Lacroix S, Vallières L, Nadeau S, Zhang J, Laflamme N. How the blood talks to the brain parenchyma and the paraventricular nucleus of the hypothalamus during systemic inflammatory and infectious stimuli. Proc Soc Exp Biol Med (2000) 223:22-38. doi:10.1111/j.1525-1373.2000.22304.x

11. Watkins LR, Goehler LE, Relton JK, Tartaglia N, Silbert L, Martin D, et al. Blockade of interleukin-1 induced hyperthermia by subdiaphragmatic vagotomy: evidence for vagal mediation of immune-brain communication. Neurosci Lett (1995) 183:27-31. doi:10.1016/0304-3940(94)11105-R

12. Capuron L, Miller AH. Immune system to brain signaling: neuropsychopharmacological implications. Pharmacol Ther (2011) 130:226-38. doi:10.1016/j. pharmthera.2011.01.014

13. Pereda MP, Lohrer P, Kovalovsky D, Perez Castro C, Goldberg V, Losa M, et al. Interleukin-6 is inhibited by glucocorticoids and stimulates ACTH secretion and POMC expression in human corticotroph pituitary adenomas. Exp Clin Endocrinol Diabetes (2000) 108:202-7. doi:10.1055/s-2000-7887

14. Turrin NP, Rivest S. Unraveling the molecular details involved in the intimate link between the immune and neuroendocrine systems. Exp Biol Med (Maywood) (2004) 229:996-1006. doi:10.1177/153537020422901003

15. Cruz-Topete D, Cidlowski JA. One hormone, two actions: anti- and pro-inflammatory effects of glucocorticoids. Neuroimmunomodulation (2015) 22:20-32. doi:10.1159/000362724

16. Howell MP, Muglia LJ. Effects of genetically altered brain glucocorticoid receptor action on behavior and adrenal axis regulation in mice. Front Neuroendocrinol (2006) 27:275-84. doi:10.1016/j.yfrne.2006.05.001

17. Kleiman A, Tuckermann JP. Glucocorticoid receptor action in beneficial and side effects of steroid therapy: lessons from conditional knockout mice. Mol Cell Endocrinol (2007) 275:98-108. doi:10.1016/j.mce.2007.05.009

18. Barnes PJ, Adcock IM. Glucocorticoid resistance in inflammatory diseases. Lancet (2009) 373:1905-17. doi:10.1016/S0140-6736(09)60326-3

19. Bertini R, Bianchi M, Ghezzi P. Adrenalectomy sensitizes mice to the lethal effects of interleukin 1 and tumor necrosis factor. J Exp Med (1988) 167:1708-12. doi:10.1084/jem.167.5.1708

20. Edwards CK III, Yunger LM, Lorence RM, Dantzer R, Kelley KW. The pituitary gland is required for protection against lethal effects of Salmonella typhimurium. Proc Natl Acad Sci U S A (1991) 88:2274-7. doi:10.1073/ pnas.88.6.2274

21. MacPhee IA, Antoni FA, Mason DW. Spontaneous recovery of rats from experimental allergic encephalomyelitis is dependent on regulation of the immune system by endogenous adrenal corticosteroids. J Exp Med (1989) 169:431-45. doi:10.1084/jem.169.2.431

22. Ramachandra RN, Sehon AH, Berczi I. Neuro-hormonal host defence in endotoxin shock. Brain Behav Immun (1992) 6:157-69. doi:10.1016/ 0889-1591(92)90015-G

23. Refojo D, Liberman AC, Giacomini D, Carbia Nagashima A, Graciarena M, Echenique C, et al. Integrating systemic information at the molecular level: cross-talk between steroid receptors and cytokine signaling on different target cells. Ann N Y Acad Sci (2003) 992:196-204. doi:10.1111/j.1749-6632.2003. tb03150.x

24. Ruzek MC, Pearce BD, Miller AH, Biron CA. Endogenous glucocorticoids protect against cytokine-mediated lethality during viral infection. J Immunol (1999) 162:3527-33.
25. Evans RM. The steroid and thyroid hormone receptor superfamily. Science (1988) 240:889-95. doi:10.1126/science.3283939

26. Kumar R, Thompson EB. Gene regulation by the glucocorticoid receptor: structure: function relationship. J Steroid Biochem Mol Biol (2005) 94:383-94. doi:10.1016/j.jsbmb.2004.12.046

27. Beck IM, Vanden Berghe W, Vermeulen L, Yamamoto KR, Haegeman G, De Bosscher K. Crosstalk in inflammation: the interplay of glucocorticoid receptor-based mechanisms and kinases and phosphatases. Endocr Rev (2009) 30:830-82. doi:10.1210/er.2009-0013

28. Glass CK, Rose DW, Rosenfeld MG. Nuclear receptor coactivators. Curr Opin Cell Biol (1997) 9:222-32. doi:10.1016/S0955-0674(97)80066-X

29. Bledsoe RK, Montana VG, Stanley TB, Delves CJ, Apolito CJ, McKee DD, et al. Crystal structure of the glucocorticoid receptor ligand binding domain reveals a novel mode of receptor dimerization and coactivator recognition. Cell (2002) 110:93-105. doi:10.1016/S0092-8674(02)00817-6

30. Cain DW, Cidlowski JA. Specificity and sensitivity of glucocorticoid signaling in health and disease. Best Pract Res Clin Endocrinol Metab (2015) 29:545-56. doi:10.1016/j.beem.2015.04.007

31. Oakley RH, Cidlowski JA. Cellular processing of the glucocorticoid receptor gene and protein: new mechanisms for generating tissue-specific actions of glucocorticoids. J Biol Chem (2011) 286:3177-84. doi:10.1074/jbc.R110. 179325

32. Busillo JM, Azzam KM, Cidlowski JA. Glucocorticoids sensitize the innate immune system through regulation of the NLRP3 inflammasome. J Biol Chem (2011) 286:38703-13. doi:10.1074/jbc.M111.275370

33. Ligr M, Li Y, Logan SK, Taneja S, Melamed J, Lepor H, et al. Mifepristone inhibits GRbeta coupled prostate cancer cell proliferation. J Urol (2012) 188:981-8. doi:10.1016/j.juro.2012.04.102

34. Lewis-Tuffin LJ, Jewell CM, Bienstock RJ, Collins JB, Cidlowski JA. Human glucocorticoid receptor beta binds RU-486 and is transcriptionally active. Mol Cell Biol (2007) 27:2266-82. doi:10.1128/MCB.01439-06

35. Charmandari E, Chrousos GP, Ichijo T, Bhattacharyya N, Vottero A, Souvatzoglou E, et al. The human glucocorticoid receptor (hGR) beta isoform suppresses the transcriptional activity of hGRalpha by interfering with formation of active coactivator complexes. Mol Endocrinol (2005) 19:52-64. doi:10.1210/me.2004-0112

36. Oakley RH, Jewell CM, Yudt MR, Bofetiado DM, Cidlowski JA. The dominant negative activity of the human glucocorticoid receptor beta isoform. Specificity and mechanisms of action. J Biol Chem (1999) 274:27857-66. doi:10.1074/jbc.274.39.27857

37. Sousa AR, Lane SJ, Cidlowski JA, Staynov DZ, Lee TH. Glucocorticoid resistance in asthma is associated with elevated in vivo expression of the glucocorticoid receptor beta-isoform. J Allergy Clin Immunol (2000) 105:943-50. doi:10.1067/mai.2000.106486

38. Chikanza IC. Mechanisms of corticosteroid resistance in rheumatoid arthritis: a putative role for the corticosteroid receptor beta isoform. Ann N Y Acad Sci (2002) 966:39-48. doi:10.1111/j.1749-6632.2002.tb04200.x

39. Honda M, Orii F, Ayabe T, Imai S, Ashida T, Obara T, et al. Expression of glucocorticoid receptor beta in lymphocytes of patients with glucocorticoid-resistant ulcerative colitis. Gastroenterology (2000) 118:859-66. doi:10.1016/ S0016-5085(00)70172-7

40. Piotrowski P, Burzynski M, Lianeri M, Mostowska M, Wudarski M, Chwalinska-Sadowska H, et al. Glucocorticoid receptor beta splice variant expression in patients with high and low activity of systemic lupus erythematosus. Folia Histochem Cytobiol (2007) 45:339-42.

41. Koga Y, Matsuzaki A, Suminoe A, Hattori H, Kanemitsu S, Hara T. Differential mRNA expression of glucocorticoid receptor alpha and beta is associated with glucocorticoid sensitivity of acute lymphoblastic leukemia in children. Pediatr Blood Cancer (2005) 45:121-7. doi:10.1002/pbc.20308

42. Shahidi H, Vottero A, Stratakis CA, Taymans SE, Karl M, Longui CA, et al. Imbalanced expression of the glucocorticoid receptor isoforms in cultured lymphocytes from a patient with systemic glucocorticoid resistance and chronic lymphocytic leukemia. Biochem Biophys Res Commun (1999) 254:559-65. doi:10.1006/bbrc.1998.9980

43. Lu NZ, Collins JB, Grissom SF, Cidlowski JA. Selective regulation of bone cell apoptosis by translational isoforms of the glucocorticoid receptor. Mol Cell Biol (2007) 27:7143-60. doi:10.1128/MCB.00253-07

44. Cain DW, Cidlowski JA. Immune regulation by glucocorticoids. Nat Rev Immunol (2017) 17:233-47. doi:10.1038/nri.2017.1 
45. Cooper MS, Stewart PM. 11Beta-hydroxysteroid dehydrogenase type 1 and its role in the hypothalamus-pituitary-adrenal axis, metabolic syndrome, and inflammation. J Clin Endocrinol Metab (2009) 94:4645-54. doi:10.1210/ jc.2009-1412

46. Stegk JP, Ebert B, Martin HJ, Maser E. Expression profiles of human 11beta-hydroxysteroid dehydrogenases type 1 and type 2 in inflammatory bowel diseases. Mol Cell Endocrinol (2009) 301:104-8. doi:10.1016/j. mce.2008.10.030

47. Zbánková S, Bryndová J, Leden $\mathrm{P}$, Kment $\mathrm{M}$, Svec A, Pácha J. 11Betahydroxysteroid dehydrogenase 1 and 2 expression in colon from patients with ulcerative colitis. J Gastroenterol Hepatol (2007) 22:1019-23. doi:10.1111/ j.1440-1746.2006.04529.x

48. Liberman AC, Antunica-Noguerol M, Arzt E. Modulation of the glucocorticoid receptor activity by post-translational modifications. Nucl Recept Res (2014) 1:1-15. doi:10.11131/2014/101086

49. Golebiowski F, Matic I, Tatham MH, Cole C, Yin Y, Nakamura A, et al. System-wide changes to SUMO modifications in response to heat shock. Sci Signal (2009) 2:ra24. doi:10.1126/scisignal.2000282

50. Holmstrom S, Van Antwerp ME, Iñiguez-Lluhi JA. Direct and distinguishable inhibitory roles for SUMO isoforms in the control of transcriptional synergy. Proc Natl Acad Sci U S A (2003) 100:15758-63. doi:10.1073/pnas. 2136933100

51. Le Drean Y, Mincheneau N, Le Goff P, Michel D. Potentiation of glucocorticoid receptor transcriptional activity by sumoylation. Endocrinology (2002) 143:3482-9. doi:10.1210/en.2002-220135

52. Tian S, Poukka H, Palvimo JJ, Jänne OA. Small ubiquitin-related modifier-1 (SUMO-1) modification of the glucocorticoid receptor. Biochem J (2002) 367:907-11. doi:10.1042/bj20021085

53. Iñiguez-Lluhí JA, Pearce D. A common motif within the negative regulatory regions of multiple factors inhibits their transcriptional synergy. Mol Cell Biol (2000) 20:6040-50. doi:10.1128/MCB.20.16.6040-6050.2000

54. Carbia-Nagashima A, Gerez J, Perez-Castro C, Paez-Pereda M, Silberstein S, Stalla GK, et al. RSUME, a small RWD-containing protein, enhances SUMO conjugation and stabilizes HIF-1alpha during hypoxia. Cell (2007) 131:309-23. doi:10.1016/j.cell.2007.07.044

55. Druker J, Liberman AC, Antunica-Noguerol M, Gerez J, Paez-Pereda M, Rein T, et al. RSUME enhances glucocorticoid receptor SUMOylation and transcriptional activity. Mol Cell Biol (2013) 33:2116-27. doi:10.1128/ MCB.01470-12

56. Paakinaho V, Kaikkonen S, Makkonen H, Benes V, Palvimo JJ. SUMOylation regulates the chromatin occupancy and anti-proliferative gene programs of glucocorticoid receptor. Nucleic Acids Res (2014) 42:1575-92. doi:10.1093/ nar/gkt1033

57. Davies L, Karthikeyan N, Lynch JT, Sial EA, Gkourtsa A, Demonacos C, et al. Cross talk of signaling pathways in the regulation of the glucocorticoid receptor function. Mol Endocrinol (2008) 22:1331-44. doi:10.1210/me. 2007-0360

58. Antunica-Noguerol M, Budziñski ML, Druker J, Gassen NC, Sokn MC, Senin $\mathrm{S}$, et al. The activity of the glucocorticoid receptor is regulated by SUMO conjugation to FKBP51. Cell Death Differ (2016) 23:1579-91. doi:10.1038/ cdd.2016.44

59. Kotaja N, Karvonen U, Jänne OA, Palvimo JJ. The nuclear receptor interaction domain of GRIP1 is modulated by covalent attachment of SUMO-1. J Biol Chem (2002) 277:30283-8. doi:10.1074/jbc.M204768200

60. Panse VG, Hardeland U, Werner T, Kuster B, Hurt E. A proteome-wide approach identifies sumoylated substrate proteins in yeast. J Biol Chem (2004) 279:41346-51. doi:10.1074/jbc.M407950200

61. Pountney DL, Raftery MJ, Chegini F, Blumbergs PC, Gai WP. NSF, Unc-18-1, dynamin-1 and HSP90 are inclusion body components in neuronal intranuclear inclusion disease identified by anti-SUMO-1-immunocapture. Acta Neuropathol (2008) 116:603-14. doi:10.1007/s00401-008-0437-4

62. Zhou W, Ryan JJ, Zhou H. Global analyses of sumoylated proteins in Saccharomyces cerevisiae. Induction of protein sumoylation by cellular stresses. J Biol Chem (2004) 279:32262-8. doi:10.1074/jbc.M404173200

63. Pratt WB, Toft DO. Regulation of signaling protein function and trafficking by the hsp90/hsp70-based chaperone machinery. Exp Biol Med (Maywood) (2003) 228:111-33. doi:10.1177/153537020322800201

64. Schülke JP, Wochnik GM, Lang-Rollin I, Gassen NC, Knapp RT, Berning B, et al. Differential impact of tetratricopeptide repeat proteins on the steroid hormone receptors. PLoS One (2010) 5:e11717. doi:10.1371/journal. pone. 0011717

65. Holownia A, Mroz RM, Kolodziejczyk A, Chyczewska E, Braszko JJ. Increased FKBP51 in induced sputum cells of chronic obstructive pulmonary disease patients after therapy. Eur J Med Res (2009) 14(Suppl 4):108-11.

66. Storer CL, Dickey CA, Galigniana MD, Rein T, Cox MB. FKBP51 and FKBP52 in signaling and disease. Trends Endocrinol Metab (2011) 22:481-90. doi:10.1016/j.tem.2011.08.001

67. Woodruff PG, Boushey HA, Dolganov GM, Barker CS, Yang YH, Donnelly S, et al. Genome-wide profiling identifies epithelial cell genes associated with asthma and with treatment response to corticosteroids. Proc Natl Acad Sci U S A (2007) 104:15858-63. doi:10.1073/pnas.0707413104

68. Matsushita R, Hashimoto A, Tomita T, Yoshitawa H, Tanaka S, Endo H, et al. Enhanced expression of mRNA for FK506-binding protein 5 in bone marrow CD34 positive cells in patients with rheumatoid arthritis. Clin Exp Rheumatol (2010) 28:87-90.

69. Baker RG, Hayden MS, Ghosh S. NF-kappaB, inflammation, and metabolic disease. Cell Metab (2011) 13:11-22. doi:10.1016/j.cmet.2010.12.008

70. Erlejman AG, De Leo SA, Mazaira GI, Molinari AM, Camisay MF, Fontana V, et al. NF-kappaB transcriptional activity is modulated by FK506-binding proteins FKBP51 and FKBP52: a role for peptidyl-prolyl isomerase activity. J Biol Chem (2014) 289:26263-76. doi:10.1074/jbc.M114. 582882

71. Hayden MS, Ghosh S. NF-kappaB in immunobiology. Cell Res (2011) 21:223-44. doi:10.1038/cr.2011.13

72. Nakamura N, Shimaoka Y, Tougan T, Onda H, Okuzaki D, Zhao H, et al. Isolation and expression profiling of genes upregulated in bone marrow-derived mononuclear cells of rheumatoid arthritis patients. DNA Res (2006) 13:169-83. doi:10.1093/dnares/dsl006

73. Park J, Kim M, Na G, Jeon I, Kwon YK, Kim JH, et al. Glucocorticoids modulate NF-kappaB-dependent gene expression by up-regulating FKBP51 expression in Newcastle disease virus-infected chickens. Mol Cell Endocrinol (2007) 278:7-17. doi:10.1016/j.mce.2007.08.002

74. Binder EB, Salyakina D, Lichtner P, Wochnik GM, Ising M, Pütz B, et al. Polymorphisms in FKBP5 are associated with increased recurrence of depressive episodes and rapid response to antidepressant treatment. Nat Genet (2004) 36:1319-25. doi:10.1038/ng1479

75. Zannas AS, Wiechmann T, Gassen NC, Binder EB. Gene-stressepigenetic regulation of FKBP5: clinical and translational implications. Neuropsychopharmacology (2016) 41:261-74. doi:10.1038/npp.2015.235

76. Zimmermann P, Brückl T, Nocon A, Pfister H, Binder EB, Uhr M, et al. Interaction of FKBP5 gene variants and adverse life events in predicting depression onset: results from a 10-year prospective community study. Am J Psychiatry (2011) 168:1107-16. doi:10.1176/appi.ajp.2011.10111577

77. De Bosscher K, Haegeman G. Minireview: latest perspectives on antiinflammatory actions of glucocorticoids. Mol Endocrinol (2009) 23:281-91. doi:10.1210/me.2008-0283

78. Desmet SJ, De Bosscher K. Glucocorticoid receptors: finding the middle ground. J Clin Invest (2017) 127:1136-45. doi:10.1172/JCI88886

79. Surjit M, Ganti KP, Mukherji A, Ye T, Hua G, Metzger D, et al. Widespread negative response elements mediate direct repression by agonist-liganded glucocorticoid receptor. Cell (2011) 145:224-41. doi:10.1016/j.cell.2011. 03.027

80. Hudson WH, Youn C, Ortlund EA. The structural basis of direct glucocorticoid-mediated transrepression. Nat Struct Mol Biol (2013) 20:53-8. doi: $10.1038 / \mathrm{nsmb} .2456$

81. Löwenberg M, Stahn C, Hommes DW, Buttgereit F. Novel insights into mechanisms of glucocorticoid action and the development of new glucocorticoid receptor ligands. Steroids (2008) 73:1025-9. doi:10.1016/j. steroids.2007.12.002

82. Boldizsar F, Talaber G, Szabo M, Bartis D, Palinkas L, Nemeth P, et al. Emerging pathways of non-genomic glucocorticoid (GC) signalling in T cells. Immunobiology (2010) 215:521-6. doi:10.1016/j.imbio.2009.10.003

83. Croxtall JD, Choudhury Q, Flower RJ. Glucocorticoids act within minutes to inhibit recruitment of signalling factors to activated EGF receptors through a receptor-dependent, transcription-independent mechanism. Br J Pharmacol (2000) 130:289-98. doi:10.1038/sj.bjp.0703272

84. Ayroldi E, Cannarile L, Migliorati G, Nocentini G, Delfino DV, Riccardi C. Mechanisms of the anti-inflammatory effects of glucocorticoids: genomic 
and nongenomic interference with MAPK signaling pathways. FASEB $J$ (2012) 26:4805-20. doi:10.1096/fj.12-216382

85. Scheinman RI, Gualberto A, Jewell CM, Cidlowski JA, Baldwin AS Jr. Characterization of mechanisms involved in transrepression of NF-kappa B by activated glucocorticoid receptors. Mol Cell Biol (1995) 15:943-53. doi:10.1128/MCB.15.2.943

86. De Bosscher K, Vanden Berghe W, Haegeman G. The interplay between the glucocorticoid receptor and nuclear factor-kappaB or activator protein-1: molecular mechanisms for gene repression. Endocr Rev (2003) 24:488-522. doi:10.1210/er.2002-0006

87. De Bosscher K, Vanden Berghe W, Haegeman G. Cross-talk between nuclear receptors and nuclear factor kappaB. Oncogene (2006) 25:6868-86. doi:10.1038/sj.onc. 1209935

88. Pascual G, Glass CK. Nuclear receptors versus inflammation: mechanisms of transrepression. Trends Endocrinol Metab (2006) 17:321-7. doi:10.1016/j. tem.2006.08.005

89. Jonat C, Rahmsdorf HJ, Park KK, Cato AC, Gebel S, Ponta H, et al. Antitumor promotion and antiinflammation: down-modulation of AP-1 (Fos/Jun) activity by glucocorticoid hormone. Cell (1990) 62:1189-204. doi:10.1016/0092-8674(90)90395-U

90. Helmberg A, Auphan N, Caelles C, Karin M. Glucocorticoid-induced apoptosis of human leukemic cells is caused by the repressive function of the glucocorticoid receptor. EMBO J (1995) 14:452-60.

91. Auphan N, DiDonato JA, Rosette C, Helmberg A, Karin M. Immunosuppression by glucocorticoids: inhibition of NF-kappa B activity through induction of I kappa B synthesis. Science (1995) 270:286-90. doi:10.1126/science.270.5234.286

92. Vacca A, Felli MP, Farina AR, Martinotti S, Maroder M, Screpanti I, et al. Glucocorticoid receptor-mediated suppression of the interleukin 2 gene expression through impairment of the cooperativity between nuclear factor of activated T cells and AP-1 enhancer elements. J Exp Med (1992) 175:637-46. doi:10.1084/jem.175.3.637

93. De Bosscher K, Schmitz ML, Vanden Berghe W, Plaisance S, Fiers W, Haegeman G. Glucocorticoid-mediated repression of nuclear factor-kappaB-dependent transcription involves direct interference with transactivation. Proc Natl Acad Sci U S A (1997) 94:13504-9. doi:10.1073/ pnas.94.25.13504

94. Liberman AC, Refojo D, Druker J, Toscano M, Rein T, Holsboer F, et al. The activated glucocorticoid receptor inhibits the transcription factor T-bet by direct protein-protein interaction. FASEB J (2007) 21:1177-88. doi:10.1096/ f. $06-7452 \mathrm{com}$

95. John S, Sabo PJ, Johnson TA, Sung MH, Biddie SC, Lightman SL, et al. Interaction of the glucocorticoid receptor with the chromatin landscape. Mol Cell (2008) 29:611-24. doi:10.1016/j.molcel.2008.02.010

96. John S, Sabo PJ, Thurman RE, Sung MH, Biddie SC, Johnson TA, et al. Chromatin accessibility pre-determines glucocorticoid receptor binding patterns. Nat Genet (2011) 43:264-8. doi:10.1038/ng.759

97. De Bosscher K, Beck IM, Haegeman G. Classic glucocorticoids versus non-steroidal glucocorticoid receptor modulators: survival of the fittest regulator of the immune system? Brain Behav Immun (2010) 24:1035-42. doi:10.1016/j.bbi.2010.06.010

98. De Bosscher K, Haegeman G, Elewaut D. Targeting inflammation using selective glucocorticoid receptor modulators. Curr Opin Pharmacol (2010) 10:497-504. doi:10.1016/j.coph.2010.04.007

99. Liberman AC, Castro CN, Antunica Noguerol MA, Barcala Tabarrozzi AE, Druker J, Perone MJ, et al. Immunomodulation by glucocorticoids: from basic research to clinical implications. Curr Immunol Rev (2010) 6:371-80.

100. Barnes PJ. Glucocorticosteroids: current and future directions. BrJ Pharmacol (2011) 163:29-43. doi:10.1111/j.1476-5381.2010.01199.x

101. Vandevyver S, Dejager L, Van Bogaert T, Kleyman A, Liu Y, Tuckermann J, et al. Glucocorticoid receptor dimerization induces MKP1 to protect against TNF-induced inflammation. J Clin Invest (2012) 122:2130-40. doi:10.1172/ JCI60006

102. Ronchetti S, Migliorati G, Riccardi C. GILZ as a mediator of the anti-inflammatory effects of glucocorticoids. Front Endocrinol (2015) 6:170. doi:10.3389/ fendo.2015.00170

103. De Bosscher K, Van Craenenbroeck K, Meijer OC, Haegeman G. Selective transrepression versus transactivation mechanisms by glucocorticoid receptor modulators in stress and immune systems. Eur J Pharmacol (2008) 583:290-302. doi:10.1016/j.ejphar.2007.11.076

104. Belvisi MG, Wicks SL, Battram CH, Bottoms SE, Redford JE, Woodman P, et al. Therapeutic benefit of a dissociated glucocorticoid and the relevance of in vitro separation of transrepression from transactivation activity. J Immunol (2001) 166:1975-82. doi:10.4049/jimmunol.166.3.1975

105. De Bosscher K, Beck IM, Dejager L, Bougarne N, Gaigneaux A, Chateauvieux $\mathrm{S}$, et al. Selective modulation of the glucocorticoid receptor can distinguish between transrepression of NF-kappaB and AP-1. Cell Mol Life Sci (2014) 71:143-63. doi:10.1007/s00018-013-1367-4

106. De Bosscher K, Vanden Berghe W, Beck IM, Van Molle W, Hennuyer N, Hapgood J, et al. A fully dissociated compound of plant origin for inflammatory gene repression. Proc Natl Acad Sci U S A (2005) 102:15827-32. doi:10.1073/pnas.0505554102

107. Vayssière BM, Dupont S, Choquart A, Petit F, Garcia T, Marchandeau C, et al. Synthetic glucocorticoids that dissociate transactivation and AP-1 transrepression exhibit antiinflammatory activity in vivo. Mol Endocrinol (1997) 11:1245-55. doi:10.1210/me.11.9.1245

108. Sugimoto MA, Vago JP, Teixeira MM, Sousa LP. Annexin Al and the resolution of inflammation: modulation of neutrophil recruitment, apoptosis, and clearance. JImmunol Res (2016) 2016:8239258. doi:10.1155/2016/ 8239258

109. Errasfa M, Russo-Marie F. A purified lipocortin shares the anti-inflammatory effect of glucocorticosteroids in vivo in mice. Br J Pharmacol (1989) 97:1051-8. doi:10.1111/j.1476-5381.1989.tb12561.x

110. Buckingham JC, John CD, Solito E, Tierney T, Flower RJ, Christian H, et al. Annexin 1, glucocorticoids, and the neuroendocrine-immune interface. Ann N Y Acad Sci (2006) 1088:396-409. doi:10.1196/annals.1366.002

111. Barczyk K, Ehrchen J, Tenbrock K, Ahlmann M, Kneidl J, Viemann D, et al. Glucocorticoids promote survival of anti-inflammatory macrophages via stimulation of adenosine receptor A3. Blood (2010) 116:446-55. doi:10.1182/ blood-2009-10-247106

112. Fadok VA, Bratton DL, Konowal A, Freed PW, Westcott JY, Henson PM. Macrophages that have ingested apoptotic cells in vitro inhibit proinflammatory cytokine production through autocrine/paracrine mechanisms involving TGF-beta, PGE2, and PAF. J Clin Invest (1998) 101:890-8. doi:10.1172/ JCI1112

113. Liu Y, Cousin JM, Hughes J, Van Damme J, Seckl JR, Haslett C, et al. Glucocorticoids promote nonphlogistic phagocytosis of apoptotic leukocytes. J Immunol (1999) 162:3639-46.

114. McColl A, Bournazos S, Franz S, Perretti M, Morgan BP, Haslett C, et al. Glucocorticoids induce protein S-dependent phagocytosis of apoptotic neutrophils by human macrophages. JImmunol (2009) 183:2167-75. doi:10.4049/jimmunol.0803503

115. Franchimont D. Overview of the actions of glucocorticoids on the immune response: a good model to characterize new pathways of immunosuppression for new treatment strategies. Ann N Y Acad Sci (2004) 1024:124-37. doi:10.1196/annals.1321.009

116. Sauer J, Castren M, Hopfner U, Holsboer F, Stalla GK, Arzt E. Inhibition of lipopolysaccharide-induced monocyte interleukin-1 receptor antagonist synthesis by cortisol: involvement of the mineralocorticoid receptor. J Clin Endocrinol Metab (1996) 81:73-9. doi:10.1210/jc.81.1.73

117. Ehrchen J, Steinmüller L, Barczyk K, Tenbrock K, Nacken W, Eisenacher M, et al. Glucocorticoids induce differentiation of a specifically activated, anti-inflammatory subtype of human monocytes. Blood (2007) 109:1265-74. doi:10.1182/blood-2006-02-001115

118. Vallelian F, Schaer CA, Kaempfer T, Gehrig P, Duerst E, Schoedon G, et al. Glucocorticoid treatment skews human monocyte differentiation into a hemoglobin-clearance phenotype with enhanced heme-iron recycling and antioxidant capacity. Blood (2010) 116:5347-56. doi:10.1182/ blood-2010-04-277319

119. Ayroldi E, Riccardi C. Glucocorticoid-induced leucine zipper (GILZ): a new important mediator of glucocorticoid action. FASEB J (2009) 23:3649-58. doi:10.1096/fj.09-134684

120. Cohen N, Mouly E, Hamdi H, Maillot MC, Pallardy M, Godot V, et al. GILZ expression in human dendritic cells redirects their maturation and prevents antigen-specific T lymphocyte response. Blood (2006) 107:2037-44. doi:10.1182/blood-2005-07-2760 
121. Elftman MD, Norbury CC, Bonneau RH, Truckenmiller ME. Corticosterone impairs dendritic cell maturation and function. Immunology (2007) 122:279-90. doi:10.1111/j.1365-2567.2007.02637.x

122. Hamdi H, Godot V, Maillot MC, Prejean MV, Cohen N, Krzysiek R, et al. Induction of antigen-specific regulatory $\mathrm{T}$ lymphocytes by human dendritic cells expressing the glucocorticoid-induced leucine zipper. Blood (2007) 110:211-9. doi:10.1182/blood-2006-10-052506

123. Hontelez S, Karthaus N, Looman MW, Ansems M, Adema GJ. DC-SCRIPT regulates glucocorticoid receptor function and expression of its target GILZ in dendritic cells. JImmunol (2013) 190:3172-9. doi:10.4049/ jimmunol.1201776

124. Luther C, Adamopoulou E, Stoeckle C, Brucklacher-Waldert V, RosenkranzD, Stoltze L, et al. Prednisolone treatment induces tolerogenic dendritic cells and a regulatory milieu in myasthenia gravis patients. JImmunol (2009) 183:841-8. doi:10.4049/jimmunol.0802046

125. Rutella S, Lemoli RM. Regulatory $\mathrm{T}$ cells and tolerogenic dendritic cells: from basic biology to clinical applications. Immunol Lett (2004) 94:11-26. doi:10.1016/j.imlet.2004.04.015

126. Cao Y, Bender IK, Konstantinidis AK, Shin SC, Jewell CM, Cidlowski JA, et al. Glucocorticoid receptor translational isoforms underlie maturational stage-specific glucocorticoid sensitivities of dendritic cells in mice and humans. Blood (2013) 121:1553-62. doi:10.1182/blood-2012-05-432336

127. Cronstein BN, Kimmel SC, Levin RI, Martiniuk F, Weissmann G. A mechanism for the antiinflammatory effects of corticosteroids: the glucocorticoid receptor regulates leukocyte adhesion to endothelial cells and expression of endothelial-leukocyte adhesion molecule 1 and intercellular adhesion molecule 1. Proc Natl Acad Sci U S A (1992) 89:9991-5. doi:10.1073/ pnas.89.21.9991

128. Pitzalis C, Pipitone N, Bajocchi G, Hall M, Goulding N, Lee A, et al. Corticosteroids inhibit lymphocyte binding to endothelium and intercellular adhesion: an additional mechanism for their anti-inflammatory and immunosuppressive effect. J Immunol (1997) 158:5007-16.

129. Pitzalis C, Pipitone N, Perretti M. Regulation of leukocyte-endothelial interactions by glucocorticoids. Ann N Y Acad Sci (2002) 966:108-18. doi:10.1111/j.1749-6632.2002.tb04208.x

130. Weber PS, Toelboell T, Chang LC, Tirrell JD, Saama PM, Smith GW, et al. Mechanisms of glucocorticoid-induced down-regulation of neutrophil L-selectin in cattle: evidence for effects at the gene-expression level and primarily on blood neutrophils. J Leukoc Biol (2004) 75:815-27. doi:10.1189/ jlb.1003505

131. Besedovsky L, Born J, Lange T. Endogenous glucocorticoid receptor signaling drives rhythmic changes in human T-cell subset numbers and the expression of the chemokine receptor CXCR4. FASEB J (2014) 28:67-75. doi:10.1096/f.13-237958

132. Fischer HJ, Schweingruber N, Lühder F, Reichardt HM. The potential role of $\mathrm{T}$ cell migration and chemotaxis as targets of glucocorticoids in multiple sclerosis and experimental autoimmune encephalomyelitis. Mol Cell Endocrinol (2013) 380:99-107. doi:10.1016/j.mce.2013.04.001

133. Reichardt HM, Kaestner KH, Tuckermann J, Kretz O, Wessely O, Bock R, et al. DNA binding of the glucocorticoid receptor is not essential for survival. Cell (1998) 93:531-41. doi:10.1016/S0092-8674(00)81183-6

134. Bouillet P, Metcalf D, Huang DC, Tarlinton DM, Kay TW, Köntgen F, et al. Proapoptotic Bcl-2 relative Bim required for certain apoptotic responses, leukocyte homeostasis, and to preclude autoimmunity. Science (1999) 286:1735-8. doi:10.1126/science.286.5445.1735

135. Knudson CM, Tung KS, Tourtellotte WG, Brown GA, Korsmeyer SJ. Baxdeficient mice with lymphoid hyperplasia and male germ cell death. Science (1995) 270:96-9. doi:10.1126/science.270.5233.96

136. Villunger A, Michalak EM, Coultas L, Müllauer F, Böck G, Ausserlechner MJ, et al. p53- and drug-induced apoptotic responses mediated by $\mathrm{BH} 3-$ only proteins puma and noxa. Science (2003) 302:1036-8. doi:10.1126/ science. 1090072

137. Yin XM, Wang K, Gross A, Zhao Y, Zinkel S, Klocke B, et al. Bid-deficient mice are resistant to Fas-induced hepatocellular apoptosis. Nature (1999) 400:886-91. doi:10.1038/23730

138. Purton JF, Monk JA, Liddicoat DR, Kyparissoudis K, Sakkal S, Richardson SJ, et al. Expression of the glucocorticoid receptor from the 1A promoter correlates with $\mathrm{T}$ lymphocyte sensitivity to glucocorticoid-induced cell death. J Immunol (2004) 173:3816-24. doi:10.4049/jimmunol.173.6.3816
139. Mosmann TR, Coffman RL. TH1 and TH2 cells: different patterns of lymphokine secretion lead to different functional properties. Annu Rev Immunol (1989) 7:145-73. doi:10.1146/annurev.iy.07.040189.001045

140. Farrar JD, Ouyang W, Löhning M, Assenmacher M, Radbruch A, Kanagawa $\mathrm{O}$, et al. An instructive component in $\mathrm{T}$ helper cell type 2 (Th2) development mediated by GATA-3. JExp Med (2001) 193:643-50. doi:10.1084/jem.193.5.643

141. Ivanov II, McKenzie BS, Zhou L, Tadokoro CE, Lepelley A, Lafaille JJ, et al. The orphan nuclear receptor RORgammat directs the differentiation program of proinflammatory IL-17+ T helper cells. Cell (2006) 126:1121-33. doi:10.1016/j.cell.2006.07.035

142. Yang XO, Pappu BP, Nurieva R, Akimzhanov A, Kang HS, Chung Y, et al. $T$ helper 17 lineage differentiation is programmed by orphan nuclear receptors ROR alpha and ROR gamma. Immunity (2008) 28:29-39. doi:10.1016/j. immuni.2007.11.016

143. Campbell DJ, Ziegler SF. FOXP3 modifies the phenotypic and functional properties of regulatory T cells. Nat Rev Immunol (2007) 7:305-10. doi:10.1038/nri2061

144. Ramírez F, Fowell DJ, Puklavec M, Simmonds S, Mason D. Glucocorticoids promote a TH2 cytokine response by CD4+ T cells in vitro. J Immunol (1996) 156:2406-12.

145. Franchimont D, Galon J, Gadina M, Visconti R, Zhou Y, Aringer M, et al. Inhibition of Th1 immune response by glucocorticoids: dexamethasone selectively inhibits IL-12-induced Stat4 phosphorylation in T lymphocytes. J Immunol (2000) 164:1768-74. doi:10.4049/jimmunol.164.4.1768

146. Barnes PJ. Th2 cytokines and asthma: an introduction. Respir Res (2001) 2:64-5. doi:10.1186/rr39

147. Liberman AC, Druker J, Refojo D, Holsboer F, Arzt E. Glucocorticoids inhibit GATA-3 phosphorylation and activity in T cells. FASEB J (2009) 23:1558-71. doi:10.1096/fi.08-121236

148. Maneechotesuwan K, Yao X, Ito K, Jazrawi E, Usmani OS, Adcock IM, et al. Suppression of GATA-3 nuclear import and phosphorylation: a novel mechanism of corticosteroid action in allergic disease. PLoS Med (2009) 6:e1000076. doi:10.1371/journal.pmed.1000076

149. Biola A, Andréau K, David M, Sturm M, Haake M, Bertoglio J, et al. The glucocorticoid receptor and STAT6 physically and functionally interact in T-lymphocytes. FEBS Lett (2000) 487:229-33. doi:10.1016/ S0014-5793(00)02297-3

150. Banuelos J, Cao Y, Shin SC, Lu NZ. Immunopathology alters Th17 cell glucocorticoid sensitivity. Allergy (2017) 72:331-41. doi:10.1111/all.13051

151. Ziolkowska M, Koc A, Luszczykiewicz G, Ksiezopolska-Pietrzak K, Klimczak E, Chwalinska-Sadowska H, et al. High levels of IL-17 in rheumatoid arthritis patients: IL-15 triggers in vitro IL-17 production via cyclosporin A-sensitive mechanism. J Immunol (2000) 164:2832-8. doi:10.4049/ jimmunol.164.5.2832

152. Momcilović M, Miljković Z, Popadić D, Marković M, Savić E, Ramić Z, et al. Methylprednisolone inhibits interleukin-17 and interferon-gamma expression by both naive and primed T cells. BMC Immunol (2008) 9:47. doi:10.1186/1471-2172-9-47

153. McKinley L, Alcorn JF, Peterson A, Dupont RB, Kapadia S, Logar A, et al. TH17 cells mediate steroid-resistant airway inflammation and airway hyperresponsiveness in mice. J Immunol (2008) 181:4089-97. doi:10.4049/ jimmunol.181.6.4089

154. Ramesh R, Kozhaya L, McKevitt K, Djuretic IM, Carlson TJ, Quintero MA, et al. Pro-inflammatory human Th17 cells selectively express P-glycoprotein and are refractory to glucocorticoids. JExp Med (2014) 211:89-104. doi:10.1084/jem.20130301

155. Schewitz-Bowers LP, Lait PJ, Copland DA, Chen P, Wu W, Dhanda AD, et al. Glucocorticoid-resistant $\mathrm{Th} 17$ cells are selectively attenuated by cyclosporine A. Proc Natl Acad Sci U S A (2015) 112:4080-5. doi:10.1073/pnas.1418316112

156. Banuelos J, Shin S, Cao Y, Bochner BS, Morales-Nebreda L, Budinger GR, et al. BCL-2 protects human and mouse Th17 cells from glucocorticoid-induced apoptosis. Allergy (2016) 71:640-50. doi:10.1111/all.12840

157. Zhao J, Lloyd CM, Noble A. Th17 responses in chronic allergic airway inflammation abrogate regulatory T-cell-mediated tolerance and contribute to airway remodeling. Mucosal Immunol (2013) 6:335-46. doi:10.1038/mi.2012.76

158. Chen X, Murakami T, Oppenheim JJ, Howard OMZ. Differential response of murine $\mathrm{CD} 4+\mathrm{CD} 25+$ and $\mathrm{CD} 4+\mathrm{CD} 25-\mathrm{T}$ cells to dexamethasone-induced cell death. Eur J Immunol (2004) 34:859-69. doi:10.1002/eji.200324506 
159. Chen X, Oppenheim JJ, Winkler-Pickett RT, Ortaldo JR, Howard OM. Glucocorticoid amplifies IL-2-dependent expansion of functional FoxP3(+) CD4(+)CD25(+) T regulatory cells in vivo and enhances their capacity to suppress EAE. Eur J Immunol (2006) 36:2139-49. doi:10.1002/eji. 200635873

160. Braitch M, Harikrishnan S, Robins RA, Nichols C, Fahey AJ, Showe L, et al. Glucocorticoids increase CD4CD25 cell percentage and Foxp3 expression in patients with multiple sclerosis. Acta Neurol Scand (2009) 119:239-45. doi:10.1111/j.1600-0404.2008.01090.x

161. Engler JB, Kursawe N, Solano ME, Patas K, Wehrmann S, Heckmann N, et al. Glucocorticoid receptor in $\mathrm{T}$ cells mediates protection from autoimmunity in pregnancy. Proc Natl Acad Sci U S A (2017) 114:E181-90. doi:10.1073/ pnas. 1617115114

162. Wüst S, van den Brandt J, Tischner D, Kleiman A, Tuckermann JP, Gold R, et al. Peripheral T cells are the therapeutic targets of glucocorticoids in experimental autoimmune encephalomyelitis. J Immunol (2008) 180:8434-43. doi:10.4049/jimmunol.180.12.8434

163. Olsen PC, Kitoko JZ, Ferreira TP, de-Azevedo CT, Arantes AC, Martins MA. Glucocorticoids decrease Treg cell numbers in lungs of allergic mice. Eur J Pharmacol (2015) 747:52-8. doi:10.1016/j.ejphar.2014.11.034

164. Sorrells SF, Caso JR, Munhoz CD, Sapolsky RM. The stressed CNS: when glucocorticoids aggravate inflammation. Neuron (2009) 64:33-9. doi:10.1016/j. neuron.2009.09.032

165. Butler LD, Layman NK, Riedl PE, Cain RL, Shellhaas J, Evans GF, et al. Neuroendocrine regulation of in vivo cytokine production and effects: I. In vivo regulatory networks involving the neuroendocrine system, interleukin-1 and tumor necrosis factor-alpha. J Neuroimmunol (1989) 24:143-53. doi:10.1016/0165-5728(89)90108-2

166. Goujon E, Parnet P, Cremona S, Dantzer R. Endogenous glucocorticoids down regulate central effects of interleukin-1 beta on body temperature and behaviour in mice. Brain Res (1995) 702:173-80. doi:10.1016/0006-8993(95)01041-9

167. Goujon E, Parnet P, Layé S, Combe C, Dantzer R. Adrenalectomy enhances pro-inflammatory cytokines gene expression, in the spleen, pituitary and brain of mice in response to lipopolysaccharide. Brain Res Mol Brain Res (1996) 36:53-62. doi:10.1016/0169-328X(95)00242-K

168. Masferrer JL, Seibert K, Zweifel B, Needleman P. Endogenous glucocorticoids regulate an inducible cyclooxygenase enzyme. Proc Natl Acad Sci U S A (1992) 89:3917-21. doi:10.1073/pnas.89.9.3917

169. Drew PD, Chavis JA. Inhibition of microglial cell activation by cortisol. Brain Res Bull (2000) 52:391-6. doi:10.1016/S0361-9230(00)00275-6

170. Tanaka J, Fujita H, Matsuda S, Toku K, Sakanaka M, Maeda N. Glucocorticoidand mineralocorticoid receptors in microglial cells: the two receptors mediate differential effects of corticosteroids. Glia (1997) 20:23-37. doi:10.1002/ (SICI) 1098-1136(199705)20:1<23::AID-GLIA3>3.0.CO;2-6

171. Glezer I, Munhoz CD, Kawamoto EM, Marcourakis T, Avellar MC, Scavone C. MK-801 and 7-Ni attenuate the activation of brain NF-kappa B induced by LPS. Neuropharmacology (2003) 45:1120-9. doi:10.1016/ S0028-3908(03)00279-X

172. Blais V, Turrin NP, Rivest S. Cyclooxygenase 2 (COX-2) inhibition increases the inflammatory response in the brain during systemic immune stimuli. J Neurochem (2005) 95:1563-74. doi:10.1111/j.1471-4159.2005.03480.x

173. Blais V, Zhang J, Rivest S. In altering the release of glucocorticoids, ketorolac exacerbates the effects of systemic immune stimuli on expression of proinflammatory genes in the brain. Endocrinology (2002) 143:4820-7. doi:10.1210/en.2002-220598

174. Nadeau S, Rivest S. Endotoxemia prevents the cerebral inflammatory wave induced by intraparenchymal lipopolysaccharide injection: role of glucocorticoids and CD14. J Immunol (2002) 169:3370-81. doi:10.4049/ jimmunol.169.6.3370

175. Nadeau S, Rivest S. Glucocorticoids play a fundamental role in protecting the brain during innate immune response. J Neurosci (2003) 23:5536-44. doi:10.1523/JNEUROSCI.23-13-05536.2003

176. Soulet D, Rivest S. Bone-marrow-derived microglia: myth or reality? Curr Opin Pharmacol (2008) 8:508-18. doi:10.1016/j.coph.2008.04.002

177. Carrillo-de Sauvage MÁ, Maatouk L, Arnoux I, Pasco M, Sanz Diez A, Delahaye $\mathrm{M}$, et al. Potent and multiple regulatory actions of microglial glucocorticoid receptors during CNS inflammation. Cell Death Differ (2013) 20:1546-57. doi:10.1038/cdd.2013.108
178. Frank MG, Miguel ZD, Watkins LR, Maier SF. Prior exposure to glucocorticoids sensitizes the neuroinflammatory and peripheral inflammatory responses to E. coli lipopolysaccharide. Brain Behav Immun (2010) 24:19-30. doi:10.1016/j.bbi.2009.07.008

179. Johnson JD, O'Connor KA, Deak T, Stark M, Watkins LR, Maier SF. Prior stressor exposure sensitizes LPS-induced cytokine production. Brain Behav Immun (2002) 16:461-76. doi:10.1006/brbi.2001.0638

180. Johnson JD, O'Connor KA, Hansen MK, Watkins LR, Maier SF. Effects of prior stress on LPS-induced cytokine and sickness responses. Am J Physiol Regul Integr Comp Physiol (2003) 284:R422-32. doi:10.1152/ajpregu.00230. 2002

181. Hermoso MA, Matsuguchi T, Smoak K, Cidlowski JA. Glucocorticoids and tumor necrosis factor alpha cooperatively regulate toll-like receptor 2 gene expression. Mol Cell Biol (2004) 24:4743-56. doi:10.1128/ MCB.24.11.4743-4756.2004

182. Munhoz CD, Lepsch LB, Kawamoto EM, Malta MB, Lima Lde S, Avellar MC, et al. Chronic unpredictable stress exacerbates lipopolysaccharide-induced activation of nuclear factor-kappaB in the frontal cortex and hippocampus via glucocorticoid secretion. J Neurosci (2006) 26:3813-20. doi:10.1523/ JNEUROSCI.4398-05.2006

183. de Pablos RM, Villarán RF, Argüelles S, Herrera AJ, Venero JL, Ayala A, et al. Stress increases vulnerability to inflammation in the rat prefrontal cortex. J Neurosci (2006) 26:5709-19. doi:10.1523/JNEUROSCI.0802-06.2006

184. Espinosa-Oliva AM, de Pablos RM, Villarán RF, Argüelles S, Venero JL, Machado A, et al. Stress is critical for LPS-induced activation of microglia and damage in the rat hippocampus. Neurobiol Aging (2011) 32:85-102. doi:10.1016/j.neurobiolaging.2009.01.012

185. Frank MG, Thompson BM, Watkins LR, Maier SF. Glucocorticoids mediate stress-induced priming of microglial pro-inflammatory responses. Brain Behav Immun (2012) 26:337-45. doi:10.1016/j.bbi.2011.10.005

186. Frank MG, Watkins LR, Maier SF. Stress- and glucocorticoid-induced priming of neuroinflammatory responses: potential mechanisms of stress-induced vulnerability to drugs of abuse. Brain Behav Immun (2011) 25(Suppl 1):S21-8. doi:10.1016/j.bbi.2011.01.005

187. Frank MG, Watkins LR, Maier SF. Stress-induced glucocorticoids as a neuroendocrine alarm signal of danger. Brain Behav Immun (2013) 33:1-6. doi:10.1016/j.bbi.2013.02.004

188. Blandino P Jr, Barnum CJ, Solomon LG, Larish Y, Lankow BS, Deak T. Gene expression changes in the hypothalamus provide evidence for regionallyselective changes in IL-1 and microglial markers after acute stress. Brain Behav Immun (2009) 23:958-68. doi:10.1016/j.bbi.2009.04.013

189. Frank MG, Baratta MV, Sprunger DB, Watkins LR, Maier SF. Microglia serve as a neuroimmune substrate for stress-induced potentiation of CNS pro-inflammatory cytokine responses. Brain Behav Immun (2007) 21:47-59. doi:10.1016/j.bbi.2006.03.005

190. García-Bueno B, Madrigal JL, Pérez-Nievas BG, Leza JC. Stress mediators regulate brain prostaglandin synthesis and peroxisome proliferator-activated receptor-gamma activation after stress in rats. Endocrinology (2008) 149:1969-78. doi:10.1210/en.2007-0482

191. Madrigal JL, Hurtado O, Moro MA, Lizasoain I, Lorenzo P, Castrillo A, et al. The increase in TNF-alpha levels is implicated in NF-kappaB activation and inducible nitric oxide synthase expression in brain cortex after immobilization stress. Neuropsychopharmacology (2002) 26:155-63. doi:10.1016/ S0893-133X(01)00292-5

192. Madrigal JL, Moro MA, Lizasoain I, Lorenzo P, Fernández AP, Rodrigo J, et al. Induction of cyclooxygenase- 2 accounts for restraint stress-induced oxidative status in rat brain. Neuropsychopharmacology (2003) 28:1579-88. doi:10.1038/sj.npp.1300187

193. O'Connor KA, Johnson JD, Hammack SE, Brooks LM, Spencer RL, Watkins LR, et al. Inescapable shock induces resistance to the effects of dexamethasone. Psychoneuroendocrinology (2003) 28:481-500. doi:10.1016/ S0306-4530(02)00035-5

194. Ding Y, Gao ZG, Jacobson KA, Suffredini AF. Dexamethasone enhances ATP-induced inflammatory responses in endothelial cells. J Pharmacol Exp Ther (2010) 335:693-702. doi:10.1124/jpet.110.171975

195. LannanEA, Galliher-Beckley AJ,Scoltock AB, CidlowskiJA. Proinflammatory actions of glucocorticoids: glucocorticoids and TNFalpha coregulate gene expression in vitro and in vivo. Endocrinology (2012) 153:3701-12. doi:10.1210/en.2012-1020 
196. De Bosscher K. Selective glucocorticoid receptor modulators. J Steroid Biochem Mol Biol (2010) 120:96-104. doi:10.1016/j.jsbmb.2010.02.027

Conflict of Interest Statement: The authors declare that there is no conflict of interest that could be perceived as prejudicing the impartiality of the research reported.

The reviewer LD and handling Editor declared their shared affiliation.
Copyright () 2018 Liberman, Budziñski, Sokn, Gobbini, Steininger and Arzt. This is an open-access article distributed under the terms of the Creative Commons Attribution License (CC BY). The use, distribution or reproduction in other forums is permitted, provided the original author(s) and the copyright owner are credited and that the original publication in this journal is cited, in accordance with accepted academic practice. No use, distribution or reproduction is permitted which does not comply with these terms. 